\title{
Cukorbetegek önbevalláson alapuló életminőségének és betegségterhének vizsgálata
}

\author{
Kicsák Marian, ${ }^{(1)}$ Lukács Andrea dr., (2) Gaál Zsolt dr..
}

\begin{abstract}
Ósszefoglalás
A diabetes mellitus kialakulása és annak kezelése az egyén életének, életvezetésének, társas kapcsolatainak, életmódjának számos dimenzióját negativan befolyásolhatja, és ez az életminöségének romlását eredményezheti. Éppen ezért fontos, hogy a páciens szemszögéböl jelzett kimeneteleket (az ún. ,patient reported outcomes"), amelyek a betegség progressziójával és a kezeléssel összefüggésbe hozható életminöség-változásokat eredményeznek, megismerjük. A tanulmány célja a cukorbetegek életminöségét és betegségterhét befolyásoló tényezök vizsgálata, valamint az 1-es és 2-es típusú felnött cukorbetegek életminöségének és betegségterhének összehasonlitása. A felmérésben 132 fö (51,5\% férfi) vett részt, a be-

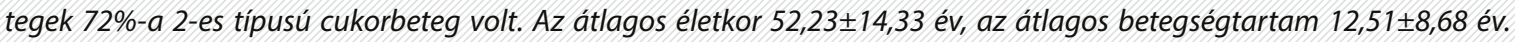
A felmérés az EuroQol (EQ-5D) és az Adapted IIIness Intrusiveness Ratings kérdöivek felhasználásával történt. Az 1-es és 2-es típusú cukorbetegek életminöség-dimenzióinak összehasonlitása khi-négyzet próbával, a betegségteher és a vizuális analóg skálán megadott egészségi állapot közötti összefüggés Pearson-féle korrelációs együtthatóval, a csoportok közötti összehasonlitás t-próbával történt. A betegségteher és az egészségi állapot meghatározó tényezöinek vizsgálatára többváltozós regressziós analizist alkalmaztak a szerzök. A betegség tipusa alapján különbség mutatkozott szinte minden vizsgált tényezöben. A 2-es tipusú cukorbetegek rosszabb egészségi állapotot, rosszabb életminöséget és nagyobb betegségterhet jeleztek.
\end{abstract}

- Kulcsszavak: 1-es típusú cukorbetegség, 2-es típusú cukorbetegség, életminöség, betegségteher

\section{Self-rated quality of life and burden of disease in patients with diabetes}

Summary: The development of diabetes mellitus and its management may have a negative impact on the lifestyle, social relationships and several dimensions of the individual's life, and this may lead to a deterioration in the quality of life. Therefore, it is important to know the patient reported outcomes, the changes in the quality of life associated with the progression of the disease and its treatment. The aim of the study was to investigate the factors influencing the quality of life and the burden of the disease in the patients with diabetes as well as to compare them by the type of the disease. A total of 132 patients $(51.5 \%$ male) participated in this survey, $72 \%$ of patients had type 2 diabetes. The average age was $52.23 \pm 14.33$ years, the average disease duration was $12.51 \pm 8.68$ years. The survey was conducted using the EuroQol (EQ5D) and the Adapted IIIness Intrusiveness Ratings questionnaires. Chi-squared test was used to compare the dimensions of the quality of life between patients with type 1 and type 2 diabetes, Pearson's correlation coefficient was applied to find an association between the burden of the disease and the health status on the visual analogue scale, and the inter-group comparison was done by $t$-test. Multivariate regression analysis was performed to find the predictors of the burden of the disease and health status. Based on the type of disease, there were differences in almost all the investigated factors. Patients with type 2 diabetes reported worse health status, worse quality of life, and increased disease burden.

Keywords: type 1 diabetes, type 2 diabetes, quality of life, burden of disease 
Rövidítések

BMI: testtömegindex (body mass index); T1DM: 1-es típusú cukorbetegség (type 1 diabetes); T2DM: 2-es típusú cukorbetegség (type 2 diabetes)

$\mathrm{C}$ ukorbetegeknél a kezelés és gondozás legfontosabb célja, hogy javítsa a beteg életkilátását és életminőségét. A terápiás evidenciákat hozó klinikai vizsgálatok (Diabetes Control and Complications Trial - DCCT, United Kingdom Prospective Diabetes Study - UKPDS) igazolták számunkra, hogy a normoglykaemiára való törekvés a kis- és nagyér-szövődményeket, valamint a diabetes okozta halálozás relatív kockázatát szignifikáns mértékben csökkenti. ${ }^{1}$ Az individualizált kezelés elsődlegesen a glykaemiás kezelési céltartomány meghatározására és elérésére fókuszál. Azonban azt is látnunk kell, hogy a munkánk során a beteg legjobb egészségi állapotáért tett erőfeszítéseink komoly tehertételt jelenthetnek a betegnek (a kezelés elfogadása és maga a kezelés), és az ő szemszögéből nézve a terápia sok esetben ronthatja az életminőséget. ${ }^{2,3}$ A diabetes mellitus kialakulása és kezelése megváltoztatja a beteg korábbi életvitelét (diéta, gyógyszerszedés/inzulinadás, vércukor-önellenőrzés). A betegnek képessé kell válnia arra, hogy helyes döntéseket hozzon a kezeléssel összefüggésben, vagy problémás helyzeteket megoldjon. A betegség és annak kezelése az egyén életének, életvezetésének, társas kapcsolatainak, életmódjának számos dimenzióját negatívan befolyásolhatja - más krónikus betegségekhez hasonlóan - és ez az életminőségének romlását eredményezheti. ${ }^{4}$ Éppen ezért különösen fontos, hogy a hagyományos orvos-biológiai paraméterek ellenőrzése mellett megismerjük a páciens szemszögéből jelzett kimeneteleket (az ún. „patient reported outcomes”), a betegség progressziójával és a terápiákkal összefüggésbe hozható életminőség-

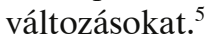

Általános értelemben az életminőség szociológiai fogalom, amely vonatkozik ,az anyagi körülmények megfelelőségére és az emberek ezen körülményekkel kapcsolatos érzéseire" (McDovell és Newel). Az orvostudomány keretein belül azonban az egészséggel összefüggő életminőséggel foglalkozunk (Health Related Quality of Life), és azt vizsgáljuk. A továbbiakban életminőség alatt az egészséggel összefüggő életminőséget értjük. Az életminőség magában foglalja a testi állapotot és működőképességet (munkaképesség, fizikai teljesítmény), a lelkiállapotot és lelki-szellemi jóllétet (elégedettség, önbecsülés, közérzet, szorongás, depresszió), valamint a szociális működést a szakmai, társas és családi területen. Figyelembe véve, hogy ezek a beteg elvárásai, percepciója, tapasztalatai és hiedelmei által befolyásolt területek. ${ }^{6}$ Egy vizsgálat során melyik dimenzió van a középpontban, általában attól függ, hogy milyen kérdés megválaszolása a cél. Általában nem egy-egy kiragadott dimenziót, hanem több dimenziót mérnek, és a mérőeszközt is ennek megfelelően választják meg. Általános és betegség-specifikus életminőség-kérdőívek állnak rendelkezésre, amelyek a legtöbb esetben gondosan kifejlesztett, pszichometriai módszerekkel bevizsgált és széles körben tesztelt mérőeszközök.

Miközben a klinikai vizsgálatokban egyre rutinszerűbben monitorozzák az életminőséget, a mindennapi klinikai gyakorlatban még nem terjedt el az életminőség mérése, pedig olyan információkhoz juthatunk általuk, amelyek a szokásos gondozás során gyüjtött klinikai adatokkal nem feltétlenül észlelhetők. A betegellátásban használt, életminőséget vizsgáló kérdőívek lehetséges előnye, hogy a beteg számára fontos problémák felismerésére, ezen belül a prioritások meghatározására kerülhet sor ily módon. További fontos előnye, hogy hatékonyabbá teheti a beteg, illetve családja és az ellátásában részt vevő szakemberek közötti kommunikációt, valamint elősegítheti a beteg részvételével történő döntéshozatalt. A beteg számára fontos szempontok figyelmen kívül hagyása nagymértékben rontja a beteg együttmüködését. ${ }^{7}$

A „betegségteher” kifejezést valamely betegség által kiváltott mindazon tényezők leírására vezették be, amelyek az egyén életének különböző dimenziót, életmódját, mindennapos és szabadidős tevékenységeit befolyásolják, és ezáltal az egyén életminőségét rontják. A betegséggel (pl. fájdalom, annak intenzitása) és a kezeléssel kapcsolatos tényezők (pl. kezelésre fordított idő) indirekt mó- 
don, a betegségteherre gyakorolt hatásaikon keresztül befolyásolják a szubjektív jóllétet, rontják az egészséggel kapcsolatos életminőséget. ${ }^{8,9}$

Vizsgálatunk során a következő kérdések merültek fel:

1. Milyen tényezők befolyásolják a betegek életminőségét, és találunk-e különbséget az 1-es és 2-es típusú felnőtt cukorbetegek életminőségében?

2. Milyen tényezők befolyásolják a betegségterhet, és találunk-e különbséget a betegségteherben az 1-es és 2-es típusú felnőtt cukorbetegeknél?

3. A nemek között van-e különbség az életminőségben és a betegségteherben?

Kutatásunk során a nyíregyházi diabetológiai centrumban gondozás alatt álló 1-es és 2-es típusú cukorbetegeket szándékoztuk felmérni. A jelen vizsgálatunkat előtanulmánynak szánjuk, mert a felmérésbe további betegek is bevonásra kerülnek. Tanulmányunkban kerestük azokat a tényezőket, amelyek befolyásolják a betegek életminőségét és betegségterhét. Vizsgálni kívántuk még a nemek közötti eltérést az életminőségben és a betegségteherben.

\section{Anyag és módszer}

\section{Betegek}

Felmérésünkben összesen 132 fő (51,5\% férfi) vett részt a diabetológiai centrumban gondozott felnőtt cukorbetegek közül, 2016 őszén. A betegek 72\%-a 2-es típusú cukorbeteg volt. $\mathrm{Az}$ átlagos életkor 52,23 $\pm 14,33$ év, az átlagos betegségtartam

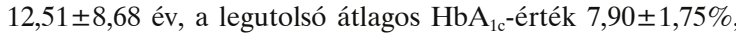
az átlagos BMI 30,78 $\pm 5,83$ volt (1. táblázat).

\section{Kérdőívek}

\section{EuroQoL (EQ-5D)}

Az egészséggel összefüggő általános életminőség mérésére használatos kérdőív. A kérdőív 5 dimenziót vizsgál 1-1 kérdésével: mozgékonyság, önellátás, szokásos napi tevékenységek, fájdalom/diszkomfortérzés, valamint szorongás/lehangoltság. Minden egyes dimenziót a súlyosságnak megfelelően 3 szinten értékelhetnek a páciensek (1. nem okoz problémát, 2. némi problémát okoz, 3. jelentős problémát okoz). A kér-

\section{1. táblázat. A diabeteses betegek jellemzői}

\begin{tabular}{|c|c|}
\hline & Átlag \pm szórás \\
\hline Mintaszám (férfi/nő) fö & $132(68 / 64)$ \\
\hline Betegség típusa: T2DM/T1DM (\%) & $72 / 28$ \\
\hline Életkor (min./max.) (év) & $52,23 \pm 14,33(18 / 80)$ \\
\hline Betegségtartam (min./max.) (év) & $12,51 \pm 8,68(1 / 42)$ \\
\hline $\mathrm{HbA}_{1 \mathrm{c}}$-érték (min./max.) (\%) & $7,90 \pm 1,75(5,2 / 14,8)$ \\
\hline BMI (min./max.) (kg/m²) & $30,78 \pm 5,83(19,19 / 50,29)$ \\
\hline
\end{tabular}

dőívhez tartozik egy vizuális analóg skála, amely egy hőmérőhöz hasonlít („egészséghőmérő”). A hőmérőn 0-tól 100-ig terjedő skálán kell a vizsgált személynek bejelölnie, hogy milyennek érzi az aktuális egészségi állapotát, ahol a 0 az elképzelhető legrosszabb egészségi állapotot jelöli, a 100 pedig az elképzelhető legjobbat.

\section{Betegségteher-kérdőív}

A betegségteher-kérdőív egy általános mérőeszköz, amely azt méri, hogy egy krónikus betegség vagy annak kezelése milyen hatást gyakorol a beteg által megélt életminőségre. Az általunk használt betegségteher-mérő kérdőív a Devins és munkatársai által fejlesztett Illness Intrusiveness Rating Scale (IIRS) adaptált változata volt. A kérdőív 13 kérdést tartalmaz, és 5 alskálát vizsgál: egészségérzet és étrend (1. és 2. kérdés), munka és anyagi helyzet (3. és 6. kérdés), házastársi, szexuális és családi kapcsolatok (7., 8. és 9. kérdés), pihenés és társas kapcsolatok (4., 5. és 10. kérdés), valamint az élet más területei, mint a vallás, civil és közösségi élet, önfejlesztő és önkifejező tevékenységek (11., 12. és 13. kérdés). A vizsgált személyek egy 7 fokozatú Likert-skálán adták meg, hogy a betegség, illetve annak kezelése milyen mértékben befolyásolja az életüket (1 - egyáltalán nem, 7 - nagymértékben). A magasabb érték nagyobb betegségterhet jelent.

\section{Demográfiai és klinikai adatok}

A demográfiai és klinikai adatokra külön kérdeztünk rá, illetve a hiányzó adatokhoz a betegek egészségügyi kartonjaiból jutottunk hozzá. A felmérésünk során az utolsó mért $\mathrm{HbA}_{1 c^{-}}$ értéket vettük figyelembe. A testtömegindexet a felmérés során mért testmagasságból és testtömegből számítottuk ki.

\section{Kutatási engedély}

A vizsgálatot a Jósa András Oktatókórház kutatási engedélyének birtokában végeztük. A betegek írásban tájékoztatást 
kaptak a vizsgálat módjáról és arról, hogy a részvétel önkéntes. A felmérésben csak azok vettek részt, akik beleegyezésüket adták.

\section{Statisztikai módszerek}

Az adatokat átlagban és szórásban, a minimum, maximum értéket feltüntetve, valamint százalékban mutattuk be. Khínégyzet próbával hasonlítottuk össze az 1-es és 2-es típusú cukorbetegek életminőség-dimenzióit. Pearson korrelációs együtthatóval jellemeztük a betegségteher és a vizuális analóg skálán megadott egészségi állapot közötti összefüggést, és t-próbát alkalmaztunk a csoportok közötti összehasonlításra. Többváltozós regressziós analízist végeztünk a betegségteher és az egészségi állapot meghatározó tényezőinek vizsgálatára az SPSS 22.0 statisztikai szoftver segítségével 95\%-os valószínűségi szint mellett.

\section{Eredmények}

\section{Életminőség}

A betegek elsősorban a fájdalomra/rossz közérzetre (EQ-5D_4) (57,6\%), a szorongásra/lehangoltságra (EQ-5D_5) (47\%), valamint a mozgékonyságban jelentkező problémákra (EQ-5D_1)

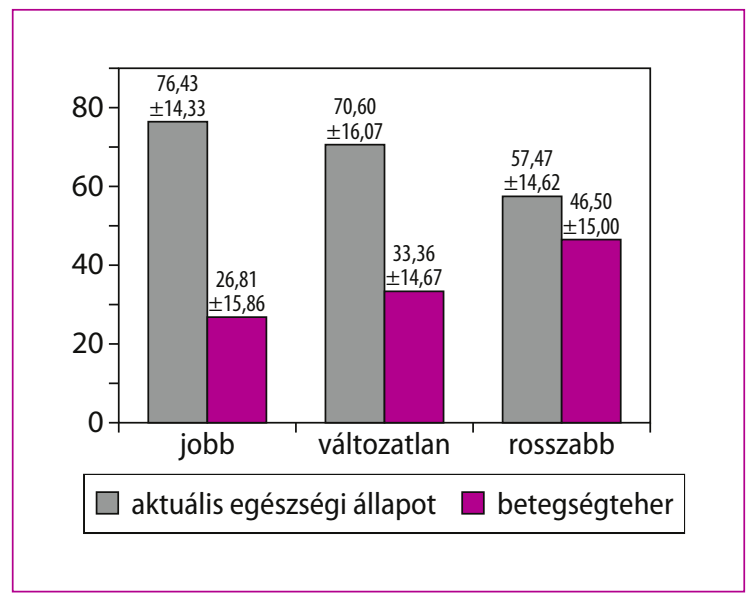

1. ábra. Az egészségi állapotban bekövetkezett változás összefüggése az aktuális egészségi állapottal és a betegségteherrel

Egészségi állapot: $F=11,098, p \leq 0,001$

Betegségteher: $F=12,511, p \leq 0,001$
(44\%) panaszkodtak. A betegség típusa alapján az EQ-5D majdnem minden moduljában a T2DMbetegek rosszabb állapotot jeleztek, mint az 1-es típusú cukorbetegek (EQ-5D_1: $\chi^{2}=16,966$, $\mathrm{p}<0,001 ;$ EQ-5D_2: $\chi^{2}=4,674, \mathrm{p}<0,031 ; \mathrm{EQ}-5 \mathrm{D} \_4$ : $\chi^{2}=7,141, \quad \mathrm{p}<0,028 ; \quad$ EQ-5D_5: $\quad \chi^{2}=7,171$, $\mathrm{p}<0,028)$. Az elmúlt évhez képest a megkérdezettek 61,4\%-a nem érzett változást, 15,9\%-a javulást érzett az egészségi állapotában. A vizsgált személyek a vizuális analóg skálán átlagosan 68,55 $\pm 16,65 \%$-ra értékelték az egészségi állapotukat. A T1DM-betegek $(75,46 \pm 16,04)$ szignifikánsan jobbnak vélték egészségi állapotukat, mint a T2DM-betegek $(65,85 \pm 16,18 ; p=0,003)$. Az aktuális egészségi állapot magyarázó tényezője a BMI $(\mathrm{t}=-3,068 ; \mathrm{p}=0,003)$, az életkor $(\mathrm{t}=-2,254$; $\mathrm{p}=0,026)$ és az iskolai végzettség volt $(\mathrm{t}=2,207$; $\mathrm{p}=0,029)\left(\mathrm{r}=0,416, \mathrm{r}^{2}=0,173\right)$. Sem az életminőségi modulokban, sem az aktuális egészségi állapotban nem találtunk különbséget a férfiak és nők között.

\section{Betegségteher}

A betegeknek a legnagyobb nehézséget a kedvezőtlen egészségérzetük és az étrend megoldása okozta $(4,19 \pm 1,46)$, a megfelelő munka és az elfogadható anyagi helyzet biztosítása $(3,56 \pm 1,85)$, valamint a házastársi, szexuális és családi kapcsolatokban rejlő probléma megoldása jelentette $(2,46 \pm 1,40)$. A betegségteher a T2DM-es csoportban szignifikánsan magasabb volt $(36,91 \pm 16,61)$, mint a T1DM-es csoportban $(31,19 \pm 14,03$; $\mathrm{p}=0,049$ ), ellenben a férfiak és a nők között nem volt különbség. A betegségterhet a diabetes időtartama $(\mathrm{t}=4,064 ; \mathrm{p}<0,001)$ és a diabetes típusa $(\mathrm{t}=2,913 ; \mathrm{p}=0,004)$ magyarázta szignifikánsan $\left(\mathrm{r}=0,369 ; \mathrm{r}^{2}=0,136\right)$.

Kapcsolatot találtunk a betegségteher és az aktuális egészségállapot között $(\mathrm{r}=-0,532$, $\mathrm{p}<0,001)$. Ez a kapcsolat szignifikáns volt akkor is, amikor a diabetes típusa alapján ellenőriztük (T1DM: $r=-0,455, p=0,005$; T2DM: $r=-0,535$, $\mathrm{p}<0,001)$. Az egészségi állapotban történ változás (jobb / változatlan / rosszabb az egészségi állapot a felmérés napján az elmúlt 12 hónapban tapasztalt általános egészségi állapothoz képest,) kimutatható volt az aktuális egészségi állapotban és a betegségteherben is (1. ábra). 


\section{Megbeszélés}

A jelen kutatásunkban az 1-es és 2-es típusú felnőtt cukorbetegek életminőségét, aktuális egészségi állapotát, valamint a betegségterhét vizsgáltuk. Legfontosabb megállapításunk az, hogy a betegség típusa alapján különbséget találtunk szinte minden vizsgált tényezőben. A 2-es típusú cukorbetegek rosszabb egészségi állapotot - az EQ-5D majdnem minden moduljában rosszabb állapotot - és nagyobb betegségterhet jeleztek. Korábbi tanulmányok is alátámasztják ezt az eredményünket, miszerint a T1DM-betegek életminősége kedvezőbb. ${ }^{7}$ A nemzetközi szakirodalomban a jobb életminőség szoros összefüggést mutat a jobb vércukorkontrollal, a fiatalabb életkorral, a kevesebb szövődménnyel. Jobb a betegek életminősége magasabb társadalmi-gazdasági státusz, házastársi kapcsolat esetén, jobb életminőséget mértek férfiaknál. ${ }^{10}$ Felmérésünkben a kedvezőbb egészségi állapot érzését a magasabb iskolai végzettség, a fiatalabb életkor és az alacsonyabb testtömegindex befolyásolja kedvezően. Nem volt különbség az életminőségben a nemek között. A vizsgálati eredmények alapján úgy gondoljuk, hogy elsődlegesen a testtömeg csökkentése az a lehetőség, amivel javítani lehet a betegeknél az egészségi állapotukkal kapcsolatos érzést. Clarke és munkatársai ötéves követéses vizsgálatukban (T2DM-betegek, $\mathrm{n}=7348$ ) azt találták, hogy az EQ-5D index független prediktora a szövődmények bekövetkezésének: 0,1 ponttal magasabb EQ-5D index (jobb egészségi állapot) esetén 7\%-kal kisebb a vascularis, $13 \%$-kal az egyéb szövődmények előfordulása, 14\%-kal alacsonyabb a mortalitási arány. ${ }^{11} \mathrm{Ez}$ az egyszerű, néhány percet igénybe vevő, önkitöltős kérdőív olyan többletinformációt ad a cukorbeteg állapotáról, amely hasznosítható a gondozási gyakorlatban. A beteg számára fontos problémák felismerhetők, célzott támogatást tudunk nyújtani. A betegségteher-vizsgálat eredményeinek tükrében valamennyi gondozott beteg részére ajánlani lehet a dietetikai edukáció lehetőségét, miután a legnagyobb „terhet” a diéta betartása jelenti. B szintű evidencia, hogy a jó életminőség és a hatékony önmenedzselés jelentős eredménye az oktatásnak. ${ }^{12}$ A dietetikai oktatásnak személyre szabottnak kell lennie, figyelembe véve a páciens képességeit. Minél egyszerűbb edukációs módszereket kell alkalmazni. Olyan ismereteket adni, amely a beteg szükségletén alapul, önkezelési gyakorlatába „azonnal” beilleszthető. Az ismeretátadáson túl elsősorban a diétával kapcsolatos készségeket és a problémamegoldó képességet kell fejleszteni. Az életminőséggel kapcsolatos vizsgálatok azt mutatják, hogy a problémamegoldó képesség összefügg a jobb életminőséggel. A nagyobb tudás, az önkezeléshez való pozitív hozzáállás, a jó egyéni kontroll módosítja a betegségteher mértékét, annak életminőséget rontó hatásait. A cukorbetegek egészségmagatartásának, megbirkózási stratégiáinak fejlesztése a sikeres kezelés és a jó életminőség egyik záloga. ${ }^{8,13}$ Vizsgálatunkkal azt kívántuk bemutatni, hogy az életminőség-vizsgálatoknak a klinikai gyakorlatban is lehet szerepe. A cukorbetegek életminőségének és betegségterhének a klinikai gyakorlatban történő monitorozása lehetőséget adhat arra, hogy a beteg számára fontos problémák felismerhetővé váljanak, és így egyénre szabott támogatásokat (klinikai, edukációs, életvezetési, pszichológiai) lehessen nyújtani. 


\section{lrodalom}

1. Winkler G, Tamás Gy: Elörehaladás a diabetológiában: az inzulin felfedezése utáni időszak fontosabb tudománytörténeti és klinikai eseményei. Diabetologia Hungarica 2012; 20: 167-178.

2. Bradley, C, Speight J: Patient perceptions of diabetes and diabetes therapy: assesing quality of life. Diabetes Metab Res Rev 2002; 18(Suppl. 3): S64-69. doi:10.1002/dmrr.279

3. Bradley, C: Importance of differentiating health status from quality of life. Lancet 2001; 357: 7-8. doi:10.1016/50140-6736(00)03562-5

4. Novák M, Véber 0, Mucsil. Egészséggel kapcsolatos életminöség cukorbetegek körében. Népegészségügy 2009; 87: 105-110.

5. Péntek M, Brodszky V, Érsek K, Jelenics N, Jermendy Gy, Winkler G, et al.: Inzulinnal kezelt felnőtt korú cukorbetegek egészségi állapota és életminősége - háziorvosi praxisokban, illetve szakellátó helyeken gondozott 480 beteg keresztmetszeti vizsgálata. Diabetologia Hungarica 2008: 16: 249-260.

6. Nord E, Arnesten T, Mensel P: Towards a more restricted use of the term "Quality of Life". QoL Newsletter 2001; 26: 3-4.

7. Novák M, Stauder A, Mucsi I: Az életminöség vizsgálatának jelentôsége és gyakorlati szempontjai. Orv Hetil 2003; 144: 1031-1038.

8. Novák M, Stauder A, Szeifert L, Mucsi I: Krónikus betegek életminóségének mérése: Betegségteher Index ("Illness Intrusiveness Rating Scale") (in: Kopp $M$, Kovács ME /szerk.:: A magyar népesség életminösége az ezredfordulón. Semmelweis Kiadó, Budapest, 2006) pp. 406-411.

9. Devins GM: Using the illness intrusiveness ratings scale to understand healthrelated quality of ife in chronic disease. J Psychosom Res 2010; 68: 591-602. doi:10.1016/j.jpsychores.2009.05.006
10. Garatt AM, Schmidt L, Fitzpatrick R: Patient-assessed health outcome measures for diabetes: a structured review. Diabet Med 2002; 19: 1-11. doi:10.1046/j.1464-5491.2002.00650.x

11. Clarke PM, Hayes AJ, Glesziou PG, Scott R, Simes J, Keech AC: Using the ED-5D index score as a predictor of outcomes in patients with type 2 diabetes. Med Care 2009; 47: 61-68. doi:10.1097/MLR.0b013e3181844855.

12. Standards of Medical Care in Diabetes - 2017. Diabetes Care 2017; 40 (Supp.1): https://doi.org/10.2337/dc17-S001

13. DESG Teaching Letter Nr. 29. Quality of life an Outcome of Diabetes Education. www.desg.org

Közlésre érkezett: 2017. július 17.

Közlésre elfogadva: 2017 . november 2.

\section{A levelezésért felelős szerző:}

\section{Kicsák Marian}

Jósa András Oktatókórház, IV. Belgyógyászati

Osztály

4400 Nyíregyháza, Szent István út 68.

E-mail cím: kicsakm@t-online.hu 